\title{
Curd and whey proteins in the nutrition of low birthweight babies
}

\author{
H. M. BERGER, P. H. SCOTT, CAROLINE KENWARD, P. SCOTT, AND B. A. WHARTON
}

Sorrento Maternity Hospital and Selly Oak Hospital, Birmingham

SUMMARY Some animals thrive more satisfactorily on a milk that contains whey and curd protein. For this reason human milk protein (which contains about $40 \%$ whey) may have some advantages over cows' milk protein (which contains about $15 \%$ whey) and so infants feeding formulae based on demineralised whey in which the protein has been modified to achieve a curd:whey ratio similar to that in human milk may also thrive more satisfactorily. As the exact situation in the human newborn is unclear, the effects of feeding a formula containing unmodified cows' milk protein (mainly curd) and one containing the same amount of modified cows' milk protein (curd and whey) were studied in 57 low birthweight babies during the first 3 months of life. During the early weeks of life the curd and whey group grew bigger, absorbed more nitrogen, and excreted proportionately less urea. These results suggest that a curd and whey formula has advantages in the protein nutrition of low birthweight babies, especially the preterm ones. We feel it would be unwise to reduce the protein content of a formula based on cows' milk below $15 \mathrm{~g} / \mathrm{l}$ unless it was modified to achieve a larger proportion of whey protein and hence, among other qualities, more cysteine. Although some of the qualities of human milk protein can be mimicked by the use of demineralised whey formulae, others cannot.

Some animals thrive more satisfactorily on a milk that contains whey and curd protein, but the significance of this for the human baby is unclear. It is relevant to re-examine this point because of recent trends in infant feeding practice.

Whey protein (lactalbumin) is more effective in promoting the growth of rats, dogs, mice, and chicks than curd protein (casein) (Mueller and Cox, 1947); it is also more effective in regenerating the plasma albumin of protein-depleted dogs (Chow et al., 1948), and in rats it has a higher 'biological value'-that is, retention of absorbed nitrogen is greater (Tomarelli and Bernhart, 1962). The significance of these observations for the human baby is not known. Empirically cows' milk protein (containing $<15 \%$ of whey protein compared with $>40 \%$ in human milk protein) has for many years been used with satisfaction for infant feeding; growth velocities of

Academic Hospital, Amsterdam

H. M. BERGER, consultant paediatrician

Sorrento Maternity Hospital, Birmingham

B. A. WHARTON, consultant paediatrician

Biochemistry Department, Selly Oak Hospital, Birmingham

P. H. SCOTT, senior biochemist

CAROLINE KENWARD, technician

P. SCOTT, head of department babies receiving a predominantly curd protein formula were similar to those receiving a curd and whey formula (Natelson et al., 1955; Barness et al., 1963), and nitrogen retention on cows' milk was similar to that of human milk (Waterlow et al., 1960).

The Medical Research Council and Agricultural Research Council (1974) drew attention to two recent changes in the understanding of protein metabolism. Firstly, although the effective aminoacid patterns of human and cows' milk protein may be similar, the nutritive value of milk proteins does not depend only on the component amino-acidse.g. the absorption of intact peptides by the intestine indicates that proteins of similar amino-acid pattern might, nevertheless, be handled quite differently. Secondly, a developmental deficiency in the newborn of the liver enzyme cystathionase may prevent adequate conversion of the high methionine content of curd protein into cysteine, so limiting nitrogen retention and making cysteine - an essential aminoacid for the newborn (Gaull et al., 1972).

Empirically two trends in infant feeding make it relevant to reinvestigate the matter. Firstly, the reduction in protein concentration of infant feeding formulae to $1 \cdot 5-1 \cdot 8 \mathrm{~g}$ per $100 \mathrm{ml}-\mathrm{i}$.e. well below that in cows' milk-makes consideration of protein 
quality in these formulae more important than when most babies received formulae containing about $3.5 \mathrm{~g}$ cows' milk protein per $100 \mathrm{ml}$. The Department of Health and Social Security (1974) stated that the lower protein formulae should supply the 'essential amino-acids in amounts at least equal to those in an equal volume of breast milk'. More importantly, however, formulae based on demineralised whey are now available-such as Gold Cap SMA-S26, Osterfeed, and Cow and Gate Premium. One advantage of these formulae is their lower mineral content but, in addition, the curd:whey protein ratio has been altered to a value similar to that of human milk. This has a teleological appeal but it is unclear whether it has any other advantages.

For these reasons we studied the nutritional effects of curd and whey protein by comparing babies fed on two formulae: one based on demineralised whey with a curd:whey ratio similar to that in breast milk (group 1) and one containing unmodified cows' milk protein-i.e. mainly curd protein (group 2).

\section{Patients and methods}

Formulae. Fig. 1 gives details of the formulae used. The curd and whey formula was based on Gold Cap SMA-S26, and the curd formula was SMA. They were manufactured in special batches for this study by the manufacturer, John Wyeth, and the fat blend was identical. The main difference was the quality of the protein-predominantly curd protein in SMA given to group 2; curd and whey protein in the S26 given to group 1. However, as a result of the demineralisation process, the sodium and potassium concentrations in S26 were lower than those in SMA (Table 1). At reconstitution of the feeds, therefore, extra sodium ( $5 \mathrm{mmol} / \mathrm{l}$ as citrate) and extra potassium ( $4 \mathrm{mmol} / 1$ as citrate, $2 \mathrm{mmol} / 1$ as chloride) were added to the $\mathbf{S} 26$ to bring the concentrations of sodium, potassium, and chloride up to those in SMA. Citrate and chloride were chosen as the other anions because they are the main milk anions (Jenness and Sloan, 1970) and also because this combination lessened the differences in the electrolyte concentrations and acid base characteristics of the two formulae. There were still differences however; although the buffering capacity was similar, the $\mathrm{pH}$ was higher while the titratable acidity was lower than in the curd formula; we were unable to devise any method of eliminating this difference without introducing others. There was one other (unwanted) difference between the two formulae. The curd and whey formula contained less calcium and phosphate, thus partly reflecting its lower casein content (Jenness and Sloan, 1970).

Table 1 shows the composition of the reconstituted formulae and also the composition of human milk and unmodified cows' milk. In the curd and whey formula only $41 \%$ of the nitrogen was casein, so it contained more cysteine than the curd formula in which $82 \%$ of the nitrogen was casein.

Patients. Table 2 gives details of the patients. Beginning in January 1974 all low birthweight babies weighing $1 \cdot 75-2 \cdot 26 \mathrm{~kg}$ admitted to the special care baby unit of the Sorrento Maternity Hospital, entered the study if their mothers were unable to provide breast milk and had given their informed consent. Babies with severe respiratory distress requiring more than $40 \%$ ambient oxygen and not able to tolerate tube feeding were not studied.

Feeding regimen. The first feeds were given within 4 hours of birth to babies nursed initially at the optimum environmental temperature (Hey, 1971), subsequently aiming to maintain rectal temperature at $36 \cdot 5-37 \cdot 5^{\circ} \mathrm{C}$. Indwelling polyvinyl intragastric

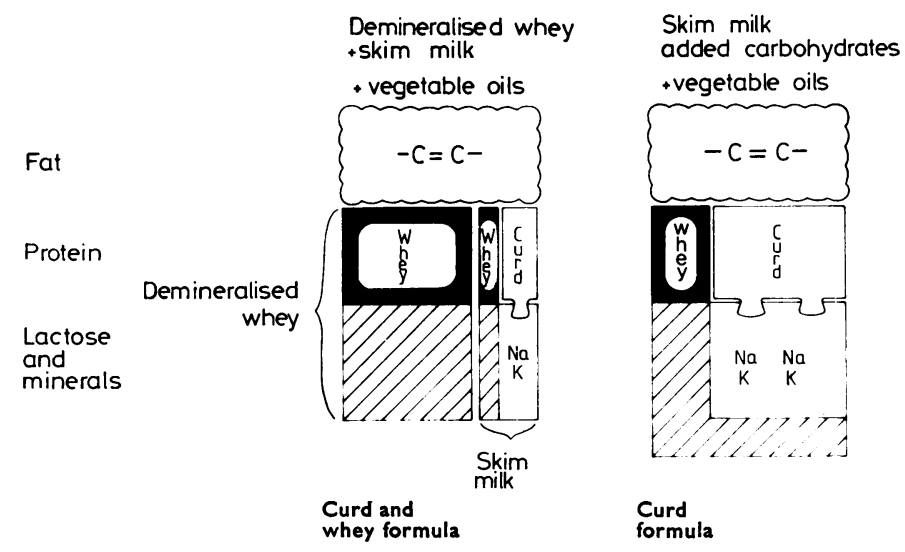

Fig. 1 The constituents of the demineralised whey formulae and the curd formula.

(Reproduced by kind permission of the British Medical Journal (Wharton and Berger, 1976)). 
Table 1 Constituents of curd and curd whey formula, mature human breast milk and unmodified cows milk (per litre whole milk)

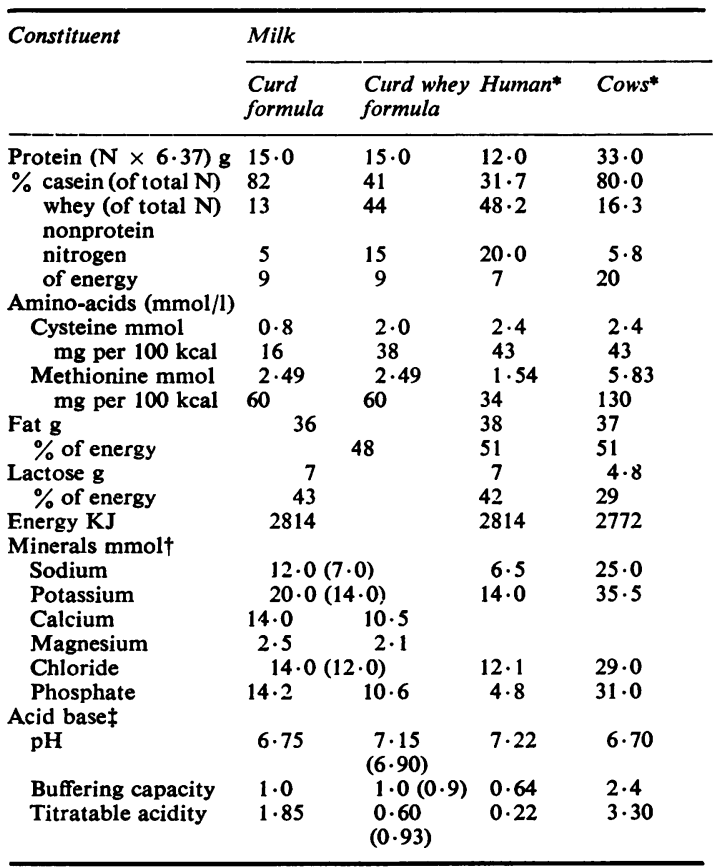

* Derived from Macie and Kelly (1961).

†Figures in parentheses are values before adding electrolyte. $\ddagger$ Derived experimentally (Berger et al., 1978).

Buffering capacity: $\mathrm{ml} 0.1 \mathrm{mmol} / 1$ hydrochloric acid to lower $\mathrm{pH}$ to 5.5; titratable acidity: $\mathrm{ml} 0.25 \mathrm{mmol} / 1$ sodium bicarbonate to raise $\mathrm{pH}$ to $7 \cdot 45$.

Table 2 Details of babies

\begin{tabular}{lll}
\hline Babies & \multicolumn{2}{l}{ Feeding formula } \\
\cline { 2 - 3 } & Curd & Curd and whey \\
\hline Number & \multicolumn{2}{l}{} \\
$\quad$ Starting trial & 37 & 33 \\
Withdrawn in first 21 days & $8^{*}$ & $5 \dagger$ \\
Number & & \\
Completing 21 days & 29 & 28 \\
Gestation (completed weeks) & & \\
Mean \pm SD & $36 \cdot 2 \pm 2 \cdot 1$ & $36 \cdot 3 \pm 2 \cdot 0$ \\
Range & $(33-40)$ & $(33-40)$ \\
Preterm & 16 & 17 \\
Term & 13 & 11 \\
Male & 18 & 15 \\
Asian & 6 & 10 \\
Number completing 90 days $\$$ & 12 & 12
\end{tabular}

* Lactation established 1, severe RDS 1, IV treatment for hypoglycaemia 1 , parenteral antibiotics 2 , convulsion 3 .

†Lactation established 2, early discharge possible 1, parenteral antibiotics 2 .

†Determined from reliable maternal dates or method described by Dubowitz et al., 1970.

$\S \S$ Left trial after 21 days: 21 did not keep to trial formulae for various reasons, 12 did not attend for follow-up. tubes were used if necessary. Appropriate weightfor-dates babies (weight 10-90th centile for gestation, Gairdner and Pearson, 1971) received $40 \mathrm{ml} / \mathrm{kg}$ during the first 24 hours of life, the volume increasing by $20 \mathrm{ml} / \mathrm{kg}$ each day, reaching $200 \mathrm{ml}$ by the 9th day. Small-for-dates babies (weight $<10$ th centile) received $60 \mathrm{ml} / \mathrm{kg}$ on the $1 \mathrm{st}$ day, increasing by $30 \mathrm{ml} / \mathrm{kg}$ each day, reaching $200 \mathrm{ml}$ by day 6 . Thereafter, the volume remained at $200 \mathrm{ml} / \mathrm{kg}$ per day until day 21, after which the mothers were advised to give approximately $200 \mathrm{ml} / \mathrm{kg}$ per day according to appetite. For volume calculations, birthweight was used until this had been regained and then the volume was recalculated after each twice-weekly weighing. Plasma bilirubin concentrations exceeded $170 \mu \mathrm{mol} / 1(9.9 \mathrm{mg} / 100 \mathrm{ml})$ in 11 of group 2 and in 14 of group 1, so extra sterile water (30\% of the above volume) was given to each baby until the bilirubin level had fallen to $170 \mu \mathrm{mol} / 1$ for 24 hours. As plasma bilirubin concentrations exceeded $250 \mu \mathrm{mol} / 1(14.6 \mathrm{mg} / 100 \mathrm{ml})$ in 3 babies in group 2 and 6 in group 1 , these babies received phototherapy until these levels were below $220 \mu \mathrm{mol} / 1$ $(12.9 \mathrm{mg} / 100 \mathrm{ml})$.

\section{Method of assessment and analysis.}

\section{Anthropometry}

This was performed at birth and at intervals thereafter by H.M.B. (Weight: Salter spring balance; length: Harpenden neonatometer; head and midarm circumference: steel tape measure; skinfold thickness: Harpenden skin calipers.

\section{Plasma biochemistry}

Samples of blood were collected by heel prick on days $2,7,11$, and 21 , four hours after the 6 a.m. feed. On days 60 and 90 parents were asked to give no milk for 8 hours before arrival but to give dextrose water as necessary.

The samples of blood were spun down within one hour and the plasma separated and stored at $-20^{\circ} \mathrm{C}$ until analysis as follows: albumin (Northam and Widdowson, 1967), urea by application of the Berthelot reaction after enzymatic hydrolysis with urease, calcium (Baginski et al., 1973), and phosphate (Itaya and Ui, 1966).

\section{Nitrogen balance and partition}

24-hour samples of urine were collected from 17 baby boys on days 3,10 , and 19 . Collection was made directly into a polyethylene container kept on ice and containing one thymol crystal. The urine was deep frozen until it was analysed for uric acid (Caraway, 1955), amino nitrogen (Goodwin, 1970), total nitrogen (Shahinian and Reinhold, 1971), urea and creatinine by standard autoanalyser methods. 
Nitrogen balances were performed (Fomon, 1974) on 7 baby boys in each dietary group for 3- or 5-day periods ending on day 21 (group 1 compared with group 2 mean and SD: birthweight $2.06 \pm 0.16$ compared with $2 \cdot 04 \pm 0 \cdot 16 \mathrm{~kg}$; gestation $36 \pm 2 \cdot 1$ compared with $36 \pm 2 \cdot 5$ weeks). The total nitrogen in the formulae, urine, and faeces was determined by the method of Shahinian and Reinhold (1971).

\section{Results}

Clinical. Three of the babies in group 2 had convulsions in the first 2 days, and were withdrawn from the trial (Table 2). Neither was hypocalcaemic or hypoglycaemic but they both had low Apgar scores. Many babies did not complete 3 months, mainly because they were also receiving solid foods (usually wheat cereal). Both infant feeding formulae were well accepted with no undue vomiting, abdominal distension, or diarrhoea.

Anthropometry (Table 3). At birth the two groups of babies were similar in size apart from a slightly greater head circumference in group 1. By 21 days these babies had also become heavier and longer. This significant difference in weight gain was present in the preterm babies but not in the term light-for-dates babies (Fig. 2).

By day 90 the difference in growth was no longer significant in the small number of babies that remained in the trial. There were no differences at any age in mean skinfold thickness (using biceps, triceps, subscapular, umbilical, and quadriceps measurements) and mid upper arm muscle circumference (Gurney and Jelliffe, 1973), so the results are not given.

Plasma biochemistry (Table 4). Group 1 babies were less acidotic on days 7,11 , and 21 (these differences

Table 3 Anthropometry from birth to day 90 in the babies on curd, and curd and whey formulae.

\begin{tabular}{|c|c|c|c|}
\hline $\begin{array}{l}\text { Measurement } \\
(\text { mean } \pm S D)\end{array}$ & Birth & Day 21 & Day 90 \\
\hline \multicolumn{4}{|l|}{ Number of babies } \\
\hline Curd & $\begin{array}{l}29 \\
28\end{array}$ & $\begin{array}{l}29 \\
28\end{array}$ & $\begin{array}{l}12 \\
12\end{array}$ \\
\hline \multicolumn{4}{|l|}{ Weight (g) } \\
\hline $\begin{array}{l}\text { Curd } \\
\text { Curd and whey } \\
\text { P* }\end{array}$ & $\begin{array}{l}2051 \pm 156 \\
2091 \pm 107\end{array}$ & $\begin{array}{l}2304 \pm 204 \\
2430 \pm 140 \\
<0.01\end{array}$ & $\begin{array}{l}4486 \pm 342 \\
4728 \pm 417\end{array}$ \\
\hline \multicolumn{4}{|l|}{ Length (cm) } \\
\hline $\begin{array}{l}\text { Curd } \\
\text { Curd and whey } \\
\mathbf{P}\end{array}$ & $\begin{array}{l}45 \cdot 2 \pm 1.4 \\
45 \cdot 7 \pm 1 \cdot 0\end{array}$ & $\begin{array}{l}47.1 \pm 1.4 \\
47.9 \pm 1.1 \\
<0.05\end{array}$ & $\begin{array}{l}56 \cdot 0 \pm 1 \cdot 5 \\
56.4 \pm 1 \cdot 3\end{array}$ \\
\hline \multicolumn{4}{|c|}{ Head circumference $(\mathrm{cm})$} \\
\hline $\begin{array}{l}\text { Curd } \\
\text { Curd and whey } \\
\mathbf{P}\end{array}$ & $\begin{array}{l}31.1 \pm 0.9 \\
31.6 \pm 0.6 \\
<0.02\end{array}$ & $\begin{array}{l}32.9 \pm 1.1 \\
33.5 \pm 0.9 \\
<0.05\end{array}$ & $\begin{array}{l}38 \cdot 3 \pm 1 \cdot 1 \\
39 \cdot 1 \pm 1 \cdot 5\end{array}$ \\
\hline
\end{tabular}

*P shows significance of difference between the means of the two groups using independent $t$ test; values $>0.10$ not shown.
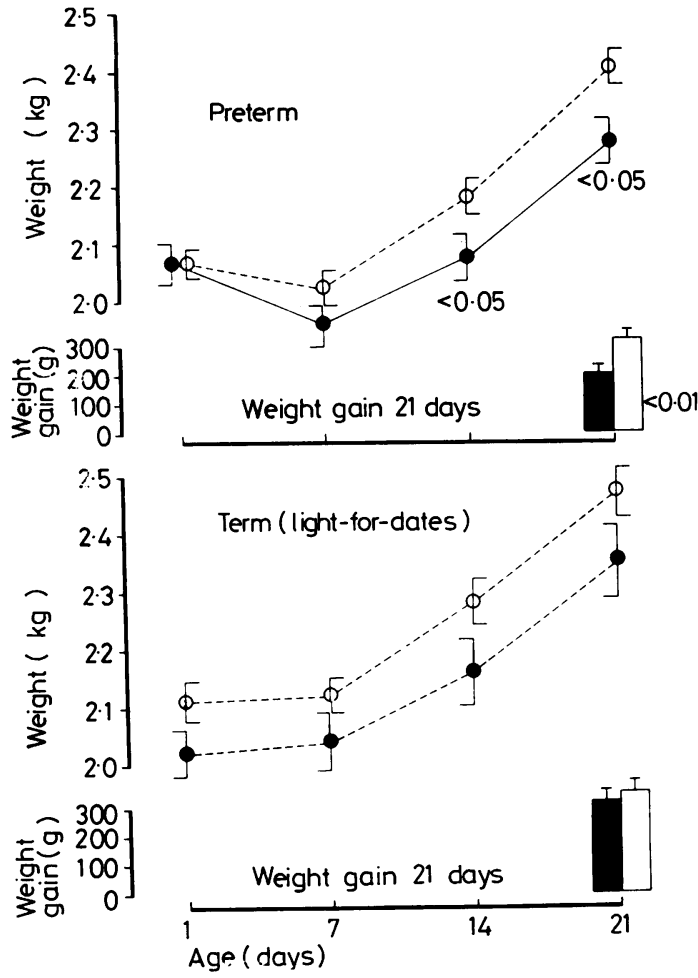

Fig. 2 Weight gain (mean $\pm S E M$ ) in preterm and term light-for-dates babies fed on curd (O) and curd and whey (0) formula. A greater increase in weight was found in the preterm but not the term light-for-dates babies fed on the curd and whey formula.

Table 4 Blood acid base status

\begin{tabular}{|c|c|c|c|c|}
\hline & Day 2 & Day 7 & Day 11 & Day 21 \\
\hline $\begin{array}{l}\text { pH } \\
\text { Curd }\end{array}$ & $\begin{array}{l}7.42 \pm 0.03 \\
(26)\end{array}$ & $7.41 \pm 0.04$ & $7 \cdot 40 \pm 0.07$ & $7.45 \pm 0.04$ \\
\hline $\begin{array}{l}\text { Curd and } \\
\text { whey }\end{array}$ & $\begin{array}{l}7.43 \pm 0.03 \\
(23)\end{array}$ & $7.44 \pm 0.04$ & $7.44 \pm 0.03$ & $7.47 \pm 0.05$ \\
\hline$\underset{\text { Carbon dio }}{\mathbf{P}}$ & de $(\mathrm{kPa})$ & $<0.02$ & $<0.01$ & $\approx 0.08$ \\
\hline Curd & $4.66 \pm 0.93$ & $3.99 \pm 0.93$ & $3.99 \pm 0.80$ & $4 \cdot 12 \pm 0 \cdot 67$ \\
\hline $\begin{array}{l}\text { Curd and } \\
\text { whey }\end{array}$ & $\begin{array}{l}5 \cdot 32 \pm 0 \cdot 80 \\
(23)\end{array}$ & $4.66 \pm 0.67$ & $4 \cdot 52 \pm 0 \cdot 80$ & $4 \cdot 39 \pm 0 \cdot 80$ \\
\hline $\begin{array}{l}\mathbf{P} \\
\text { Base excess }\end{array}$ & $\begin{array}{c}<0.02 \\
\mathrm{mmol})\end{array}$ & $<0.01$ & $<0.05$ & \\
\hline Curd & $\begin{array}{l}1 \cdot 2 \pm 2 \cdot 7 \\
(26)\end{array}$ & $-3 \cdot 1 \pm 2 \cdot 8$ & $-3 \cdot 9 \pm 3 \cdot 7$ & $-0.6 \pm 2 \cdot 8$ \\
\hline $\begin{array}{l}\text { Curd and } \\
\text { whey } \\
\text { P }\end{array}$ & $\underset{(23)}{2 \cdot 1 \pm 2 \cdot 3}$ & $\begin{array}{l}0.6 \pm 3.0 \\
<0.001\end{array}$ & $\begin{aligned} & 0.4 \pm 3.0 \\
< & 0.001\end{aligned}$ & $\begin{array}{l}2.2 \pm 2.9 \\
<0.001\end{array}$ \\
\hline $\mathbf{P}$ & & $<0.001$ & $<0.001$ & $<0.001$ \\
\hline
\end{tabular}


had disappeared by days 60 and 90 , so these results are not given). There was no correlation between base deficit on day 11 and weight gain during the first 3 weeks of life $(r=0.34)$. There was no difference in plasma concentration of albumin, urea, calcium, and phosphorus throughout the 90-day study period, so the results are not given.

Nitrogen balance and partition (Table 5; Fig. 2). Group 1 babies absorbed a significantly greater proportion of the ingested nitrogen; mean nitrogen retention was higher but not significantly so. These babies excreted less urea nitrogen in the urine (day 10) and had higher urinary urea nitrogen:total nitrogen ratios (Fig. 3).

Table 5 Nitrogen balance and urine urea excretion (mean $\pm S D$ ) of babies receiving curd, and curd and whey formulae ( $\left.\mathrm{mmol} \mathrm{kg}^{-1} 24 \mathrm{~h}^{-1}\right)$

\begin{tabular}{|c|c|c|c|}
\hline \multirow[t]{2}{*}{ Nitrogen } & \multicolumn{2}{|l|}{ Formulae } & \multirow[t]{2}{*}{$P^{*}$} \\
\hline & $\begin{array}{l}\text { Curd } \\
(n=7)\end{array}$ & $\begin{array}{l}\text { Curd and whey } \\
(n=7)\end{array}$ & \\
\hline $\begin{array}{l}\text { Intake (I) } \\
\text { Faeces (F) } \\
\text { Urine (U) } \\
\text { Absorbed (I-F) } \\
\text { Absorption as \% of } \\
\text { intake } \\
\text { Retention (I-F-U) } \\
\text { Retention as \% of } \\
\text { intake }\end{array}$ & $\begin{array}{l}35 \cdot 3 \pm 1 \cdot 1 \\
3 \cdot 1 \pm 1 \cdot 0 \\
10 \cdot 3 \pm 3 \cdot 2 \\
31 \cdot 9 \pm 1 \cdot 4 \\
90 \pm 3 \\
21 \cdot 5 \pm 3 \cdot 4 \\
61 \pm 9\end{array}$ & $\begin{array}{l}35 \cdot 5 \pm 1 \cdot 6 \\
2 \cdot 3 \pm 0 \cdot 7 \\
9 \cdot 9 \pm 2 \cdot 3 \\
33 \cdot 1 \pm 1 \cdot 5 \\
93 \pm 1 \\
23 \cdot 2 \pm 1 \cdot 1 \\
65 \pm 5\end{array}$ & $<0.03$ \\
\hline $\begin{array}{c}\text { Urinary urea } \\
\text { nitrogen } \\
\text { Day } 3 \\
\text { Day } 10 \\
\text { Days } 19\end{array}$ & $\begin{array}{l}(n=9) \\
2.07 \pm 0.57 \\
2.69 \pm 0.77 \\
3.70 \pm 1.52\end{array}$ & $\begin{array}{l}(n=8) \\
1.76 \pm 0.43 \\
1.87 \pm 0.31 \\
3.76 \pm 1.28\end{array}$ & $<0.05$ \\
\hline
\end{tabular}

*P, significance of difference between means using Mann Whitney $U$ test values $>0.10$ not shown.
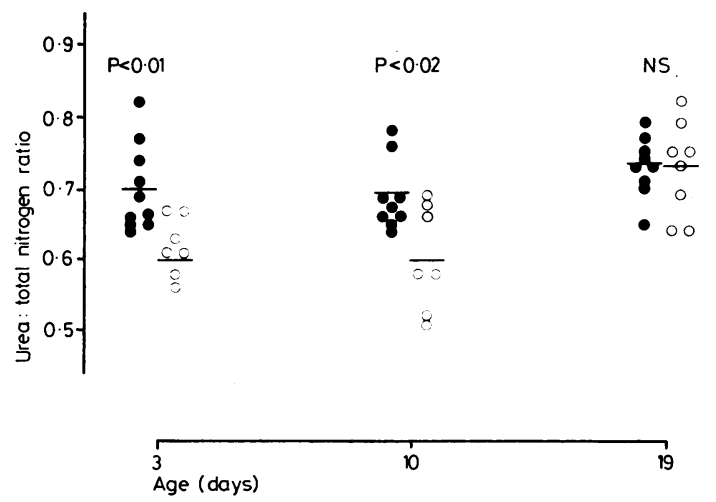

Fig. 3 Urinary urea nitrogen: total nitrogen over 3 weeks. In the curd and whey group $(O)$ the urea: total nitrogen Iratio was lower on days 3 and 10 than in the curd group $(\bullet)$.

\section{Discussion}

During the early weeks the babies in group 1 grew bigger (particularly if preterm), absorbed more nitrogen, and lost less nitrogen as urinary urea.

Were these differences in growth and nitrogen metabolism due solely to the quality of the dietary protein? There were also differences in the acid base qualities of the formulae and indeed the babies in group 1 were significantly less acidotic.

Differences in the acid base status due to the protein quality were expected (Kildeberg and Winters, 1972) and, since addition of the citrate salts to the curd and whey formula equalised the potential base in the formulae, it is probable that the differences in the base deficits were caused by the dietary protein. A lower incidence of metabolic acidosis in babies fed a curd and whey formula was also found by Räihä et al. (1976) in studies on protein quality. Whatever the cause, however, it is unlikely that these acid base findings explain the differences in growth; there was no correlation between base excess and weight gain; the degree of acidosis was generally mild, and only 4 babies had base deficits great enough to be diagnosed as late metabolic acidosis (Svenningsen and Lindquist, 1973); Heird et al. (1976) suggested that acidosis affects growth by limiting appetite but in our study babies received a prescribed volume of feed.

It seems that the differences in growth velocity and nitrogen metabolism were at least primarily related to the difference in the quality of the dietary protein.

We are uncertain which of the various qualities of whey protein accounts for these differences. Whey protein leads to quicker gastric emptying and a lower intestinal buffering capacity than curd protein (Platt, 1961; Bullen and Willis, 1971) and this may be connected with the higher nitrogen absorption in group 1, but the differences in growth and nitrogen balance may be related to the higher cysteine content of whey protein (Table 1). The curd and whey formula supplied almost as much cysteine per unit volume and energy as breast milk and, unlike the curd formula, meets the estimated cysteine requirements of $23 \mathrm{mg}$ per $100 \mathrm{kcal}(45 \mu \mathrm{mol}$ per $100 \mathrm{~kJ})$ suggested by Fomon et al., 1973. The differences in growth observed by us were not confirmed by others. Barness et al. (1963) found other biochemical differences but felt these had no clear advantage, although Räihä et al. (1976) concluded that the babies on a curd and whey formula paid a smaller 'metabolic price' to obtain their growth.

Clinical implications. Although the curd and whey formula had nutritional advantages, particularly 
in the preterm babies, these advantages were marginal. However, curd formulae containing $15 \mathrm{~g} / \mathrm{l}$ of unmodified cows' milk protein provide less cysteine than does breast milk. If the protein and, therefore, cysteine content were further reduced to lower the renal solute load, then we suspect the reduction in growth velocity might be more pronounced than we observed. We consider it would be unwise to reduce the protein content of an infant feeding formula based on cows' milk below $15 \mathrm{~g} / \mathrm{l}$ unless the protein was modified so that it included more whey protein. This caution is emphasised by susceptibility of cysteine to damage in the manufacturing processes (Pieniazek et al., 1975).

Although the protein in the curd and whey formula was modified to resemble that of breast milk, nevertheless, it is still cows' milk protein. For example, the whey fraction contains lactoglobulin, more immunogenic than casein (Lebenthal, 1975), and very little lactoferrin; the curd fraction contains $\mathrm{K}$ casein which forms micellar complexes with certain minerals, accounting for their higher content in cows' milk (Jenness and Sloan, 1970). Cows' milk contains very little free taurine.

The babies were looked after by Miss A. Frogbrook and I. Sallis and their staff; Mrs J. King and Mrs S. Doughty helped to collect specimens and analysed the results; the Department of Medical Illustration, Birmingham Children's Hospital produced the figures, H. M. Berger held a Sheldon Clinical Research Fellowship of the West Midlands Regional Health Authority and later the Mary Crosse Research Fellowship; John Wyeth gave other financial support. We are grateful to all of them and to Mrs H. Bird and Mrs P. Cox for secretarial assistance.

\section{References}

Baginski, E. S., Marie, S. S., Clark, W. L., and Zak, B. (1973). Direct microdetermination of serum calcium. Clinica chimica acta, 46, 46-54.

Barness, L. A., Omans, W. B., Rose, C. S., and György, P. (1963). Progress of premature infants fed a formula containing demineralized whey. Pediatrics, 32, 52-55.

Berger, H. M., Scott, P. H., Kenward, C., Scott, P., and Wharton, B. A. (1978). Milk pH, acid base status, and growth in babies. Archives of Disease in Childhood, 53, 926-930.

Bullen, C. L., and Willis, A. T. (1971). Resistance of the breast-fed infant to gastroenteritis. British Medical Journal, 3, 338-343.

Caraway, W. T. (1955). Determination of uric acid in serum by a carbonate method. American Journal of Clinical Pathology, 25, 841-845.

Chow, B. F., Alper, C., and De Biase, S. (1948). The effects of oral administration of different proteins on the plasma proteins of protein depleted dogs. Journal of Nutrition, 36, 785-801.

Department of Health and Social Security (1974). Present Day Practice in Infant Feeding. Reports on Health and Social Subjects No. 9, p. 25. HMSO: London.

Dubowitz, L., Dubowitz, V., and Goldberg, C. (1970). Clinical assessment of gestational age in the newborn infant. Journal of Pediatrics, 77, 1-10.

Fomon, S. J. (1974). Infant Nutrition. Saunders: Philadelphia. Fomon, S. J., Thomas, L. N., Filer, L. J., Anderson, T. A., and Bergmann, K. E. (1973). Requirements for protein and essential amino acids in early infancy. Acta paediatrica Scandinavica, 62, 33-45.

Gairdner, D., and Pearson, J. (1971). A growth chart for premature and other infants. Archives of Disease in Childhood, 46, 783-787.

Gaull, G., Sturman, J. A., and Räihä, N. C. R. (1972). Development of mammalian sulfur metabolism: absence of cystathionase in human fetal tissues. Pediatric Research, $6,538-547$.

Goodwin, J. F. (1970). Spectrophotometric quantitation of plasma and urinary amino nitrogen with fluorodinitrobenzene. Standard Methods of Clinical Chemistry, 6, 89-98.

Gurney, J. M., and Jelliffe, D. B. (1973). Arm anthropometry in nutritional assessment. American Journal of Clinical Nutrition, 26, 912-915.

Heird, W. C., MacMillan, R. W., and Winters, R. W. (1976). Total parenteral nutrition in the paediatric patient. In Total Parenteral Nutrition, p. 272. Edited by J. E. Fischer. Little Brown: Boston.

Hey, E. (1971). Recent Advances in Paediatrics, fourth edition, p. 180. Edited by D. Gairdner and D. Hull. Churchill: London.

Itaya, K., and Ui, M. (1966). A new micromethod for the colorimetric determination of inorganic phosphate. Clinica chimica acta, 14, 361-366.

Jenness, R., and Sloan, R. E. (1970). The composition of milks of various species: a review. Dairy Science Abstracts, 32, 599-612.

Kildeberg, P., and Winters, R. W. (1972). Infant feeding and blood acid base status. Pediatrics, 49, 801-802.

Lebenthal, E. (1975). Cows' milk protein allergy. Pediatric Clinics of North America, 22, 827-833.

Macie, I. G., and Kelly, J. H. (1961). Human milk and cows' milk in infant nutrition. In Milk: The Mammary Gland and Its Secretion, volume 2, p. 275 . Edited by S. K. Kon and A. T. Cowie. Academic Press: New York.

Medical Research Council and Agricultural Research Council (1974). Report: Food and Nutrition Research. HMSO: London.

Mueller, A. J., and Cox, W. M., Jr (1947). Comparative nutritive value of casein and lactalbumin for man. Journal of Nutrition, 34, 285-294.

Natelson, S., Peniall, R., Crawford, W. L., and Munsay, F. (1955). Non-casein protein to casein ratio of feeding formulas. American Journal of Diseases of Children, 89, 656-668.

Northam, B. E., and Widdowson, G. F. (1967). The Determination of Serum Albumin by AutoAnalyser using Bromcresol Green. Technical Bulletin No. 11. Association of Clinical Biochemists: London.

Pieniaźek, D., Rakowska, M., Szkiłładziowa, W., and Grabarek, Z. (1975). Estimation of available methionine and cysteine in proteins of food products by in vivo and in vitro methods. British Journal of Nutrition, 34, 175-190.

Platt, B. S. (1961). Digestion in infancy. Federation Proceedings, 20, Supplement 7, 188-195. 
Räihä, N. C. R., Heinonen, K., Rassin, D. K., and Gaull, G. E. (1976). Milk protein quality and quantity in low birth weight infants. I. Metabolic responses and effects on growth. Pediatrics, 57, 659-674.

Shahinian, A. H., and Reinhold, J. G. (1971). Application of the phenol-hypochlorite reaction to measurement of ammonia concentration in Kjeldhal digests of serum and various tissues. Clinical Chemistry, 17, 1077-1082.

Svenningsen, N. W., and Lindquist, B. (1973). Incidence of metabolic acidosis in term, preterm, and small-forgestational-age infants in relation to dietary protein intake. Ac a paediatrica Scandinavica, 62, 1-10.

Tomarelli, R. M., and Bernhart, F. W. (1962). Biological assay of milk and whey protein compositions for infant feeding. Journal of Nutrition, 78, 44-50.
Waterlow, J. C., Wills, V. G., and György, P. (1960). Balance studies in malnourished Jamaican infants. II. Comparison of absorption and retention of nitrogen and phosphorus from human milk and a cows' milk mixture. British Journal of Nutrition, 14, 199-205.

Wharton, B. A., and Berger, H. M. (1976). Bottle-feeding. British Medical Journal, 1, 1326-1331.

Correspondence to $\operatorname{Dr}$ B. A. Wharton, Child Nutrition Section, Infant Development Unit, Queen Elizabeth Medical Centre, Edgbaston, Birmingham B15 2TG.

Received 9 May 1978 